\title{
IJCIT
}

(Indonesian Journal on Computer and Information Technology) Journal Homepage: http://ejournal.bsi.ac.id/ejurnal/index.php/ijcit

\section{Pemanfaatan Machine Learning dalam Berbagai Bidang: Review paper}

\author{
Ahmad Roihan ${ }^{1}$, Po Abas Sunarya ${ }^{2}$, Ageng Setiani Rafika ${ }^{3}$ \\ ${ }^{1,3}$ Sistem Komputer, Universitas Raharja \\ Tangerang, Indonesia \\ e-mail: ahmad.roihan@raharja.info ${ }^{1}$, agengsetianirafika@raharja.info ${ }^{3}$ \\ ${ }^{2}$ Teknik Informatika, Universitas Raharja \\ Tangerang, Indonesia \\ e-mail: abas@raharja.info
}

\begin{abstract}
A B S T R A K
Pembelajaran mesin merupakan bagian dari kecerdasan buatan yang banyak digunakan untuk memecahkan berbagai masalah. Artikel ini menyajikan ulasan pemecahan masalah dari penelitianpenelitian terkini dengan mengklasifikasikan machine learning menjadi tiga kategori: pembelajaran terarah, pembelajaran tidak terarah, dan pembelajaran reinforcement. Hasil ulasan menunjukkan ketiga kategori masih berpeluang digunakan dalam beberapa kasus terkini dan dapat ditingkatkan untuk mengurangi beban komputasi dan mempercepat kinerja untuk mendapatkan tingkat akurasi dan presisi yang tinggi. Tujuan ulasan artikel ini diharapkan dapat menemukan celah dan dijadikan pedoman untuk penelitian pada masa yang akan datang.

Katakunci: pembelajaran mesin, pembelajaran reinforcement, pembelajaran terarah, pembelajaran tidak terarah

\section{ABSTRACTS}

Machine learning is part of artificial intelligence that is widely used to solve various problems. This article reviews problem solving from the latest studies by classifying machine learning into three categories: supervised learning, unsupervised learning, and reinforcement learning. The results of the review show that the three categories are still likely to be used in some of the latest cases and can be improved to reduce computational costs and accelerate performance to get a high level of accuracy and precision. The purpose of this article review is expected to be able to find a gap and it is used as a guideline for future research.
\end{abstract}

Keywords: machine learning, reinforcement learning, supervised learning, unsupervised learning

\section{PENDAHULUAN}

$\begin{gathered}\text { Secara bertahap penelitian tentang } \\ \text { penggunaan sensor semakin }\end{gathered}$
berkembang. Beberapa diantaranya digunakan
dalam proses monitoring (Ahmad Roihan,
Permana, \& Mila, 2016), alat ukur (Supriyono,
Sudarto, \& Fakhri, 2016), simulator (A. Roihan,
Sunarya, \& Wijaya, 2019), dan lain sebagainya.

Namun dalam penggunaannya tersebut masih perlu pengguna sebagai pengendali sistem dan belum menunjukkan alat dengan fungsi yang cerdas.

Seiring berlalunya waktu, mesin pintar atau cerdas perlahan-lahan akan menggantikan dan meningkatkan kemampuan manusia di berbagai bidang (Nayak \& Dutta, 2017). Kecerdasan yang ditunjukkan oleh mesin 
biasanya disebut dengan kecerdasan buatan (Artificial Intelligence) yang merupakan bagian dari ilmu komputer.

Kecerdasan Buatan merupakan salah satu bidang dalam ilmu komputer yang ditujukan pada pembuatan software dan hardware yang dapat berfungsi sebagai sesuatu yang dapat berpikir seperti manusia (Sunarya, Santoso, \& Sentanu, 2015). Kecerdasan buatan banyak digunakan untuk memecahkan berbagai masalah seperti bisnis (Rahardja, Roihan, \& others, 2017), robotika, bahasa alami, matematika, game, persepsi, diagnosis medis, teknik, analisis keuangan, analisis sains, dan penalaran (Russell \& Norvig, 2016).

Machine learning dapat didefinisikan sebagai aplikasi komputer dan algoritma matematika yang diadopsi dengan cara pembelajaran yang berasal dari data dan menghasilkan prediksi di masa yang akan datang (Goldberg \& Holland, 1988). Adapun proses pembelajaran yang dimaksud adalah suatu usaha dalam memperoleh kecerdasan yang melalui dua tahap antara lain latihan (training) dan pengujian (testing) (Huang, Zhu, \& Siew, 2006).

Bidang machine learning berkaitan dengan pertanyaan tentang bagaimana membangun program komputer agar meningkat secara otomatis dengan berdasar dari pengalaman (Mitchell, 1997).

Penelitian terkini mengungkapkan bahwa machine learning terbagi menjadi tiga kategori: Supervised Learning, Unsupervised Learning, Reinforcement Learning (Somvanshi \& Chavan, 2016). Skema keterkaitan artificial intelligence dan machine learning dapat dijelaskan dalam Gambar 1.

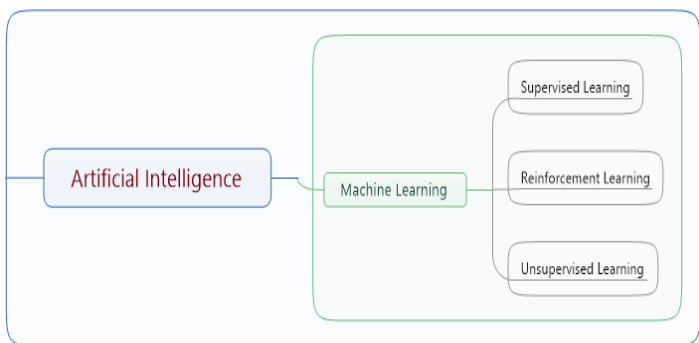

Gambar 1. Skema Artificial Intelligence dan Machine Learning

Teknik yang digunakan oleh Supervised Learning adalah metode klasifikasi di mana kumpulan data sepenuhnya diberikan label untuk mengklasifikasikan kelas yang tidak dikenal. Sedangkan teknik Unsupervised
Learning sering disebut cluster dikarenakan tidak ada kebutuhan untuk pemberian label dalam kumpulan data dan hasilnya tidak mengidentifikasi contoh di kelas yang telah ditentukan (Thupae, Isong, Gasela, \& AbuMahfouz, 2018). Sedangkan Reinforcement Learning biasanya berada antara Supervised Learning dan Unsupervised Learning (Board, 2017), teknik ini bekerja dalam lingkungan yang dinamis di mana konsepnya harus menyelesaikan tujuan tanpa adanya pemberitahuan dari komputer secara eksplisit jika tujuan tersebut telah tercapai (Das \& Nene, 2017).

Metode supervised learning didasarkan pada kumpulan sampel data yang memiliki label. Kumpulan sampel digunakan untuk meringkas karakteristik distribusi ukuran perilaku dalam setiap jenis aplikasi sehingga membentuk model perilaku dari data (Amei, Huailin, Qingfeng, \& Ling, 2011). Supervised learning dikelompokkan lebih lanjut dalam masalah klasifikasi dan regresi. Masalah klasifikasi adalah ketika variabel output berbentuk kategori, seperti merah atau biru atau penyakit dan tidak ada penyakit. Sedangkan masalah regresi adalah ketika variabel output adalah nilai riil, seperti dollar atau berat (Brownlee, 2016).

Supervised learning memiliki beberapa algoritma populer seperti Back-propagation (Negnevitsky, 2005), Linear regression, Random Forest, Support Vector Machines (Brownlee, 2016), Naive Bayesian, Metode Rocchio, Decision Tree, $k$-Nearest Neighbor, Neural Network (Darujati \& Gumelar, 2012), Logistic Regression, dan Neural Network (Lakshmi \& Sheshasaayee, 2015). Kemudian beberapa algoritma untuk klasifikasi pun disebutkan dalam seperti Support Vector Machines (SVM), Normal Bayesian Classifier (NBC), K-Nearest Neighbor (KNN), Trees Gradient Boosted (GBT), Random Trees (RT), dan Artificial Neural Networks (ANN) (Židek, Pitel', \& Hošovskl'y, 2017). Algoritma lainnya pun dibahas dalam (Athmaja, Hanumanthappa, \& Kavitha, 2017) seperti Gaussian Mixture models, Hidden Markov Models, logistic regression, Kernel Regression, Deep neural networks, Deep belief networks, PCA, Kernel Perceptron.

Beberapa masalah dalam kategori ini berkisar pada klasifikasi misalnya dalam bidang lalu lintas seperti pengembangan Automatic Plate Plate Recognition (ALPR) yang dapat digunakan di banyak aplikasi, seperti pemantauan lalu lintas jalan, pembayaran tol 
otomatis, dan manajemen parkir (Kosala, Harjoko, \& Hartati, 2017). Pemanfaatan machine learning pun dalam bidang industri dilakukan pada penelitian (Krisandi, Helmi, \& others, 2013). Selain itu dalam bidang kedokteran seperti masalah pencitraan medis (Latif, Xiao, Imran, \& Tu, 2019), pengelolaan data pasien (Khan, Doucette, Cohen, \& Lizotte, 2012) dan pemeriksaan gaya berjalan seseorang bisa diprediksi dengan akurasi yang cukup tinggi (LeMoyne, Kerr, Mastroianni, \& Hessel, 2014). Dalam bidang teknologi seperti jam pintar (Lee, Yoon, \& Lee, 2018), multimedia (Holder, Pin, \& Kalva, 2009), klasifikasi teks (Darujati \& Gumelar, 2012) dan lain sebagainya tentu saja sudah banyak yang memanfaatkan machine learning dengan kategori supervised learning.

Dalam jenis pembelajaran Unsupervised Learning, sistem disediakan dengan beberapa input sampel tetapi tidak ada output yang hadir. Karena tidak ada output yang diinginkan di sini kategorisasi dilakukan sehingga algoritma membedakan dengan benar antara kumpulan data. Ini adalah tugas mendefinisikan fungsi untuk menggambarkan struktur yang tersembunyi dari data yang tidak berlabel (Somvanshi \& Chavan, 2016). Unsupervised learning dikelompokkan lebih lanjut dalam masalah clustering dan asosiasi. Masalah pengelompokan (clustering) adalah tempat untuk menemukan pengelompokan yang melekat dalam data, seperti mengelompokkan pelanggan berdasarkan pada perilaku pembelian. Sedangkan masalah asosiasi adalah aturan yang menggambarkan sebagian besar data yang ada, seperti orang yang membeli $A$ juga cenderung membeli B (Brownlee, 2016).

Unsupervised learning memiliki beberapa algoritma populer seperti k-means, Apriori (Brownlee, 2016), Independent Subspace Analysis (ISA) (G. Wu et al., 2013), DBSCAN (Ester, Kriegel, Sander, Xu, \& others, 1996).

Beberapa masalah misalnya dalam bidang finansial untuk meninjau sejumlah besar data maka unsupervised learning biasanya dapat digunakan (Board, 2017). Dalam bidang industri misalnya dalam (Aji \& Wibisono, 2018), kemudian dalam bidang kedokteran unsupervised learning digunakan dalam proses segmentasi pembuluh darah (Dharmawan, $\mathrm{Ng}$, \& Rahardja, 2018), dan bidang teknologi seperti jaringan komputer maupun pencegahan serangan keamanannya (Das \& Nene, 2017) pun menggunakan kategori ini.
Reinforcement learning berasal dari teori belajar hewan. Pembelajaran ini tidak memerlukan pengetahuan sebelumnya, dapat secara mandiri mendapatkan kebijakan opsional dengan pengetahuan yang diperoleh melalui coba-coba dan terus berinteraksi dengan lingkungan yang dinamis (Qiang \& Zhongli, 2011). Masalah reinforcement learning diselesaikan dengan mempelajari pengalaman baru melalui trial-and-error (Mahmud, Kaiser, Hussain, \& Vassanelli, 2018). Algoritma reinforcement learning terkait dengan algoritma pemrograman dinamis yang sering digunakan untuk menyelesaikan masalah optimisasi (Mitchell, 1997).

Banyak masalah machine learning dalam dunia nyata termasuk dalam kategori ini. Hal ini dikarenakan bisa mencapai harga yang mahal bahkan memakan waktu untuk pemberian label pada data terkait kemungkinan untuk memerlukan akses ke bagian pakar. Padahal data yang tidak memiliki label itu didapatkan dengan harga yang murah dan mudah untuk dikumpulkan dan disimpan (Brownlee, 2016).

Secara khusus metode reinforcement learning berdasarkan model proses pengambilan keputusan Markov (Markov decision process) mencakup dua jenis. Pertama yaitu metode berbasis model seperti algoritma SARSA, di mana reinforcement learning pertama kali mempelajari pengetahuan model, kemudian mendapatkan strategi yang optimal dari pengetahuan model tersebut. Kedua adalah metode yang relevan model seperti algoritma Temporal Difference dan algoritma Q-learning, di mana reinforcement learning secara langsung menghitung strategi yang optimal tanpa pengetahuan model (Qiang \& Zhongli, 2011).

Beberapa masalah dalam kategori ini misalnya dalam bidang teknologi seperti pelayananan yang cerdas dengan memanfaatkan bidang loT dan kota pintar (smart city) (Mohammadi, Al-Fuqaha, Guizani, \& Oh, 2018). Dalam bidang teknologi lainnya seperti pemrosesan bahasa alami (Sharma \& Kaushik, 2017) dan computer vision (Z. Wu, Khan, Gao, \& Guan, 2018) dan (Watanabe \& Ishimaru, 2016) juga menggunakan kategori ini.

Artikel ini akan menyajikan beberapa penelitian terkini mengenai pemanfaatan algoritma machine learning berdasarkan masing-masing kategori, dengan harapan dapat menemukan celah dan dijadikan pedoman untuk penelitian pada masa yang akan datang. 


\section{METODE PENELITIAN}

Penelitian ini merupakan kajian pustaka dari beberapa artikel terkait machine learning. Peninjauan dilakukan dari beberapa upaya penelitian terbaru yang memanfaatkan machine learning. Selanjutnya kajian ini berasal dari beberapa literasi dan mencakup upaya pemecahan masalah yang dibagi ke dalam bagian bidang-bidang dari perspektif masingmasing kategori machine learning.

Proses pengumpulan data yang digunakan untuk memeriksa beberapa literatur sangat berguna untuk mencari dan memperoleh sumber kajian berdasarkan penelitian relevan sebelumnya. Teori-teori yang mendukung, data dan informasi sebagai referensi dalam dokumentasi.
Ada empat bidang yang disajikan dalam artikel ini dari kajian beberapa artikel ilmiah. Bidang-bidang tersebut adalah lalu lintas, industri, kedokteran atau medis, dan teknologi. Semua bidang ini menerangkan teknik pembelajaran apa saja yang telah digunakan oleh beberapa peneliti.

\section{HASIL DAN PEMBAHASAN}

Hasil dari ulasan menunjukkan beberapa penelitian menggunakan algoritma machine learning untuk memecahkan masalah sesuai dengan kebutuhan pada bidang masing-masing. Penjelasan mengenai pemecahan masalah dan algoritma yang digunakan secara detail ditunjukkan pada Tabel 1.

Tabel 1. Perbandingan pemecahan masalah dengan algoritma machine learning

\begin{tabular}{cl}
\hline Bidang & Keterangan \\
\hline Lalu lintas & Algoritma Convolutional Neural Network - Support Vector Machine (CNN-SVM) \\
& digunakan dalam pemecahan masalah pemilihan area plat kendaraan, sehingga dari \\
& data tersebut dapat digunakan untuk memecahkan masalah dalam pemantauan lalu \\
& lintas jalan, pembayaran tol otomatis, dan manajemen parkir. CNN bertindak sebagai \\
& metode ekstraksi fitur sedangkan SVM sebagai penggolong (classifier) (Kosala et al., \\
& 2017). Penggabungan dua algoritma ini masuk ke dalam kategori supervised learning.
\end{tabular}

Industri Algoritma k-NN dapat digunakan dalam klasifikasi data hasil produksi kelapa sawit pada PT. Minamas Kec. Parindu. Hasil produksi kelapa sawit dapat diperkirakan di masa mendatang, berkisar pada hubungan kesamaan hasil produksi antar kelompok tani (Krisandi et al., 2013). Algoritma k-NN termasuk dalam kategori supervised learning. Pengolahan data menggunakan algoritma K-means++ menghasilkan 125 jenis produk minuman yang diminati konsumen. Sementara kombinasi penjualan produk minuman hasil association rule dengan nilai confidence tertinggi (100\%) masuk dalam kluster produk diminati konsumen, dan ikut dijadikan sebagai rekomendasi dalam pengambilan keputusan penjualan (Aji \& Wibisono, 2018).

Algoritma K-means++ termasuk teknik clustering, sedangkan association rule yang dibentuk merupakan bagian dari teknik asosiasi, sehingga keduanya masuk dalam kategori Unsupervised learning.

Kedokteran Dalam analisis citra medis, algoritma deep learning membantu bidang kedokteran atau medis untuk mengkategorikan, mengklasifikasikan, dan menghitung pola penyakit dari pemrosesan gambar (Latif et al., 2019). Pemrosesan dengan teknik klasifikasi seperti ini masuk dalam kategori supervised learning.

Evaluasi kinerja dilakukan dengan menggunakan empat algoritma machine learning yang berbeda (decision stump, C4.5-R8, Bagging dan AdaBoost) dalam mendukung interoperabilitas antara berbagai sistem informasi kesehatan (Khan et al., 2012). Algoritma yang digunakan dalam evaluasi pada penelitian ini termasuk ke dalam supervised learning.

Berdasarkan atribut dari kumpulan fitur, maka regresi logistik dipilih. Mengenai pasangan hemiplegia, klasifikasi $100 \%$ dicapai melalui penerapan regresi logistik. penggunaan machine learning dapat diterapkan sebagai sistem umpan balik diagnostik untuk optimasi strategi dan dosis terapi selanjutnya dari hasil prediksi gaya berjalan seseorang (LeMoyne et al., 2014). Algoritma yang digunakan dalam proses klasifikasi 
pada penelitian ini termasuk ke dalam supervised learning.

Algoritma terbaru yang menggunakan bank filter dalam proses pencocokan dengan MDCF-II (modified Dolph-Chebyshev type II function) dan metode baru dalam menggabungkan tanggapan filter yang cocok untuk digunakan dalam proses segmentasi pembuluh darah (Dharmawan et al., 2018). Pengembangan algoritma yang digunakan dalam penelitian ini termasuk ke dalam Unsupervised learning.

Teknologi Secara keseluruhan, linear regression dipilih dalam penelitian ini karena kinerja menyeluruh dan relatif sederhana dalam hal implementasi dan pengembangannya pada platform Android yang berbasis Java. Usulan machine learning dengan tampilan user interface menjadikannya cara alternatif untuk berinteraksi dengan jam tangan pintar (Lee et al., 2018). Algoritma yang digunakan dalam penelitian ini termasuk ke dalam supervised learning.

Algoritma J4.8 (Decision Tree) berbasis machine learning dapat mengurangi kompleksitas secara signifikan dalam penelitian ini. Pendekatan machine learning yang baru dikembangkan untuk meningkatkan kinerja transcoder (Holder et al., 2009). Algoritma yang digunakan dalam penelitian ini termasuk ke dalam supervised learning. Penerapan metode naive bayes classifier dalam klasifikasi berita memiliki akurasi yang baik dapat memecahkan masalah dan teruji dengan data yang bersumber dari situs web menghasilkan nilai akurasi dengan persentase yang tinggi yaitu lebih dari $87 \%$ untuk data latih yang besar (100 artikel) (Darujati \& Gumelar, 2012). Algoritma yang digunakan dalam penelitian ini termasuk ke dalam supervised learning.

Beberapa algoritma dikemukakan dalam penelitian ini. Salah satunya terdapat K-means clustering yang menggunakan metode deteksi berbasis clustering. Keuntungan besar yang ditunjukkan oleh algoritma ini adalah membutuhkan umpan balik minimum. Setiap teknik dalam machine learning memiliki kekuatan dan kekurangannya sendiri. Tetapi secara keseluruhan, sulit untuk memilih suatu algoritma berdasar dari hal yang sama (Das \& Nene, 2017). Algoritma yang digunakan dalam penelitian survei ini cukup banyak namun untuk teknik clustering, maka metode yang dilakukan termasuk ke dalam unsupervised learning.

Penerapan model (deep reinforcement learning) yang diusulkan pada aplikasi kota pintar dilakukan untuk masalah lokalisasi dalam ruangan dengan memanfaatkan Bluetooth berkekuatan sinyal dengan rendah energi (Mohammadi et al., 2018). Algoritma yang digunakan dalam penelitian ini termasuk ke dalam reinforcement learning.

Algoritma Q-Learning digunakan untuk mempelajari tindakan optimal di setiap state yang dilalui oleh sistem melalui coba-coba. Hal ini menyelesaikan sebagian besar masalah yang terjadi di Natural Language Processing. Status tersembunyi antara input kata dan vektor output membentuk jaringan yang intensif untuk pembelajaran secara menyeluruh dan efisien (Sharma \& Kaushik, 2017). Algoritma yang digunakan dalam penelitian ini termasuk ke dalam reinforcement learning.

Algoritma Markov decision process (MDP) digunakan untuk deteksi objek gambar. Sistem yang diusulkan menggunakan agen aktif yang mengeksplorasi dalam adegan untuk mengidentifikasi target lokasi objek, dan mempelajari kebijakan untuk memperbaiki geometri agen dengan mengambil tindakan sederhana dalam ruang yang memiliki parameter berintegrasi tindakan diskrit dan parameter kontinu yang sesuai $(Z$. Wu et al., 2018). Algoritma yang digunakan dalam penelitian ini termasuk ke dalam reinforcement learning.

Metode least median of squares (LMedS) baru diusulkan dalam penelitian ini berdasarkan konsep fuzzy reinforcement learning untuk pemodelan pada aplikasi computer vision. Kinerja algoritma dievaluasi dengan cara memodelkan data sintetik dan eksperimen homografi pada kamera (Watanabe \& Ishimaru, 2016).

Algoritma yang digunakan dalam penelitian ini termasuk ke dalam reinforcement learning. 
Dengan adanya kecerdasan buatan, diharapkan tidak menutup kemungkinan hanya dengan data pengetahuan yang terbatas, sebuah komputer dapat berpikir seperti manusia dalam menghadapi masalah (Sutrisno, Kristiadi, \& Supriyanti, 2017). Tidak semua teknik bisa digunakan dalam segala bidang, namun semua algoritma yang ada dapat dikembangkan sehingga menjadi keterbaruan pengetahuan (novelty). Algoritma machine learning pun terus dikembangkan oleh beberapa penelitian. Tren terkini menunjukkan bahwa algoritma machine learning banyak dikembangkan dalam bidang kedokteran atau medis seperti yang dibahas dalam (Dharmawan, Li, Ng, \& Rahardja, 2019), (Good et al., 2019), dan (Hinton, 2018).

\section{KESIMPULAN}

Machine learning merupakan sub dari bidang keilmuan kecerdasan buatan (Artificial intelligence) yang banyak diteliti dan digunakan untuk memecahkan berbagai masalah. Ulasan dari berbagai bidang disajikan dalam bentuk pemecahan masalah dan algoritmanya dan dibagi menjadi tiga kategori dalam machine learning antara lain supervised learning, unsupervised learning, dan reinforcement learning. Ulasan dibatasi hanya pada beberapa bidang dan hasilnya menunjukkan bidang yang paling dominan terkini adalah bidang kedokteran atau medis diantara beberapa bidang lain seperti industri, teknologi dan lalu lintas.

Penelitian lanjutan dapat dianjurkan untuk mengembangkan algoritma yang ada dan menerapkannya dalam aplikasi baik berbasis desktop maupun web (Židek et al., 2017), sehingga dapat dirasakan hasilnya secara langsung oleh pengguna akhir (end user).

\section{REFERENSI}

Aji, B. P., \& Wibisono, M. A. (2018). Strategi Pengambilan Keputusan Penjualan Dalam Rangka Optimasi Profit Industri Ritel Berbasis Unsupervised Machine Learning Algorithm (Studi Kasus Modern Minimarket-X).

Amei, W., Huailin, D., Qingfeng, W., \& Ling, L. (2011). A survey of application-level protocol identification based on machine learning. 2011 International Conference on Information Management, Innovation
Management and Industrial Engineering, 3, 201-204.

Athmaja, S., Hanumanthappa, M., \& Kavitha, V. (2017). A survey of machine learning algorithms for big data analytics. 2017 International Conference on Innovations in Information, Embedded and Communication Systems (ICIIECS), 1-4.

Board, F. S. (2017). Artificial intelligence and machine learning in financial services. November, Available at: Http://Www. Fsb. Org/2017/11/Artificialintelligenceand-Machine-Learning-in-

Financialservice/(Accessed 30th January, 2018).

Brownlee, J. (2016). Master Machine Learning Algorithms: discover how they work and implement them from scratch. Jason Brownlee.

Darujati, C., \& Gumelar, A. B. (2012). Pemanfaatan Teknik Supervised Untuk Klasifikasi Teks Bahasa Indonesia. Jurnal Bandung Text Mining, 16(1), 1-5.

Das, S., \& Nene, M. J. (2017). A survey on types of machine learning techniques in intrusion prevention systems. 2017 International Conference on Wireless Communications, Signal Processing and Networking (WiSPNET), 2296-2299. https://doi.org/10.1109/WiSPNET.2017.8 300169

Dharmawan, D. A., Li, D., Ng, B. P., \& Rahardja, S. (2019). A New Hybrid Algorithm for Retinal Vessels Segmentation on Fundus Images. IEEE Access, 7, 41885-41896.

Dharmawan, D. A., Ng, B. P., \& Rahardja, S. (2018). A Modified Dolph-Chebyshev Type II Function Matched Filter for Retinal Vessels Segmentation. Symmetry, 10(7). https://doi.org/10.3390/sym10070257

Ester, M., Kriegel, H.-P., Sander, J., Xu, X., \& others. (1996). A density-based algorithm for discovering clusters in large spatial databases with noise.

Goldberg, D. E., \& Holland, J. H. (1988). Genetic algorithms and machine learning. Machine Learning, 3(2), 95-99.

Good, Z., Borges, L., Gonzalez, N. V., Sahaf, B., Samusik, N., Tibshirani, R., ... Bendall, S. C. (2019). Proliferation tracing with single-cell mass cytometry optimizes generation of stem cell memory-like T cells. Nature Biotechnology, 37(3), 259.

Hinton, G. (2018). Deep Learning: A Technology 
With the Potential to Transform Health CareThe Potential of Deep Learning Technology to Transform Health CareThe Potential of Deep Learning Technology to Transform Health Care. JAMA, 320(11), 1101-1102. https://doi.org/10.1001/jama.2018.1110 0

Holder, C., Pin, T., \& Kalva, H. (2009). Improved machine learning techniques for low complexity MPEG-2 to H. 264 transcoding using optimized codecs. 2009 Digest of Technical Papers International Conference on Consumer Electronics, 1-2.

Huang, G.-B., Zhu, Q.-Y., \& Siew, C.-K. (2006). Extreme learning machine: theory and applications. Neurocomputing, 70(1-3), 489-501.

Khan, A., Doucette, J. A., Cohen, R., \& Lizotte, D. J. (2012). Integrating machine learning into a medical decision support system to address the problem of missing patient data. 2012 11th International Conference on Machine Learning and Applications, 1, 454-457.

Kosala, G., Harjoko, A., \& Hartati, S. (2017). License Plate Detection Based on Convolutional Neural Network: Support Vector Machine (CNN-SVM). Proceedings of the International Conference on Video and Image Processing, 1-5. https://doi.org/10.1145/3177404.317743 6

Krisandi, N., Helmi, B. P., \& others. (2013). Algoritma k-Nearest Neighbor dalam Klasifikasi Data Hasil Produksi Kelapa Sawit pada PT. Minamas Kecamatan Parindu. BIMASTER, 2(1).

Lakshmi, J. V. N., \& Sheshasaayee, A. (2015). Machine learning approaches on map reduce for Big Data analytics. 2015 International Conference on Green Computing and Internet of Things (ICGCloT), 480-484.

Latif, J., Xiao, C., Imran, A., \& Tu, S. (2019). Medical Imaging using Machine Learning and Deep Learning Algorithms: A Review. 2019 2nd International Conference on Computing, Mathematics and Engineering Technologies (ICOMET), 1-5.

Lee, K.-T., Yoon, H., \& Lee, Y.-S. (2018). Implementation of smartwatch user interface using machine learning based motion recognition. 2018 International Conference on Information Networking
(ICOIN), 807-809.

LeMoyne, R., Kerr, W., Mastroianni, T., \& Hessel, A. (2014). Implementation of machine learning for classifying hemiplegic gait disparity through use of a force plate. 2014 13th International Conference on Machine Learning and Applications, 379382.

Mahmud, M., Kaiser, M. S., Hussain, A., \& Vassanelli, S. (2018). Applications of deep learning and reinforcement learning to biological data. IEEE Transactions on Neural Networks and Learning Systems, 29(6), 2063-2079.

Mitchell, T. M. (1997). Machine learning. In McGraw Hill Series in Computer Science. Retrieved from http://www.worldcat.org/oclc/61321007

Mohammadi, M., Al-Fuqaha, A., Guizani, M., \& Oh, J.-S. (2018). Semisupervised deep reinforcement learning in support of IoT and smart city services. IEEE Internet of Things Journal, 5(2), 624-635.

Nayak, A., \& Dutta, K. (2017). Impacts of machine learning and artificial intelligence on mankind. 2017 International Conference on Intelligent Computing and Control (I2C2), 1-3. https://doi.org/10.1109/I2C2.2017.83219 08

Negnevitsky, M. (2005). Artificial intelligence: a guide to intelligent systems. Pearson education.

Qiang, W., \& Zhongli, Z. (2011). Reinforcement learning model, algorithms and its application. 2011 International Conference on Mechatronic Science, Electric Engineering and Computer (MEC), 1143-1146.

Rahardja, U., Roihan, A., \& others. (2017). Design of Business Intelligence in Learning Systems Using iLearning Media. Universal Journal of Management, 5(5), 227-235.

Roihan, A., Permana, A., \& Mila, D. (2016). Monitoring Kebocoran Gas Menggunakan Mikrokontroler Arduino UNO dan ESP8266 Berbasis Internet of Things. ICIT (Innovative Creative and Information Technology), 2(2), 170-183.

Roihan, A., Sunarya, P. A., \& Wijaya, C. (2019). Auto Tee Prototype as Tee Golf Automation in Golf Simulator Studio. 2018 6th International Conference on Cyber and IT Service Management, CITSM 
2018.

https://doi.org/10.1109/CITSM.2018.867 4249

Russell, S. J., \& Norvig, P. (2016). Artificial intelligence: a modern approach. Malaysia; Pearson Education Limited,

Sharma, A. R., \& Kaushik, P. (2017). Literature survey of statistical, deep and reinforcement learning in natural language processing. 2017 International Conference on Computing, Communication and Automation (ICCCA), 350-354.

Somvanshi, M., \& Chavan, P. (2016). A review of machine learning techniques using decision tree and support vector machine. 2016 International Conference on Computing Communication Control and Automation (ICCUBEA), 1-7. https://doi.org/10.1109/ICCUBEA.2016.7 860040

Sunarya, A., Santoso, S., \& Sentanu, W. (2015). Sistem Pakar Untuk Mendiagnosa Gangguan Jaringan Lan. CCIT Journal, $8(2), 1-11$.

Supriyono, I. A., Sudarto, F., \& Fakhri, M. K. (2016). PENGUKUR TINGGI BADAN MENGGUNAKAN SENSOR ULTRASONIK BERBASIS MIKROKONTROLER ATMEGA328 DENGAN OUTPUT SUARA. CCIT Journal, 9(2), 148-156.

Sutrisno, S., Kristiadi, D. P., \& Supriyanti, D. (2017). APLIKASI SISTEM PAKAR UNTUK MENDIAGNOSA GANGGUAN JARINGAN LAN BERBASIS ANDROID DI SEKOLAH KEMURNIAN JAKARTA. SENSI Journal, 3(2), 221-239.

Thupae, R., Isong, B., Gasela, N., \& AbuMahfouz, A. M. (2018). Machine Learning Techniques for Traffic Identification and
Classifiacation in SDWSN: A Survey. IECON 2018 - 44th Annual Conference of the IEEE Industrial Electronics Society, 4645-4650.

https://doi.org/10.1109/IECON.2018.859 1178

Watanabe, T., \& Ishimaru, T. (2016). A Least Median of Squares Method Based on Fuzzy Reinforcement Learning for Modeling of Computer Vision Applications. 2016 Joint 8th International Conference on Soft Computing and Intelligent Systems (SCIS) and 17th International Symposium on Advanced Intelligent Systems (ISIS), 65-71. https://doi.org/10.1109/SCISISIS.2016.0027

Wu, G., Kim, M., Wang, Q., Gao, Y., Liao, S., \& Shen, D. (2013). Unsupervised deep feature learning for deformable registration of $\mathrm{MR}$ brain images. International Conference on Medical Image Computing and Computer-Assisted Intervention, 649-656.

Wu, Z., Khan, N. M., Gao, L., \& Guan, L. (2018). Deep Reinforcement Learning with Parameterized Action Space for Object Detection. 2018 IEEE International Symposium on Multimedia (ISM), 101104. https://doi.org/10.1109/ISM.2018.00025

Židek, K., Pitel', J., \& Hošovskl`y, A. (2017). Machine learning algorithms implementation into embedded systems with web application user interface. 2017 IEEE 21st International Conference on Intelligent Engineering Systems (INES), 77-82. 